\title{
VARIATION IN HEIGHT AND WEIGHT IN THE NORWEGIAN POPULATION
}

\author{
ERIK BJELKE \\ Cancer Registry of Norway, Oslo, Norway
}

Since 1962 , as an international collaborative project, studies have been in progress of disease among migrants and native populations in Great Britain, Norway, and the United States. The background for the first studies and data on various demographic characteristics, residential history, smoking history, and cardiorespiratory symptoms for migrants and native-born in the United States have been published elsewhere (Reid, 1966; Reid et al., 1966). For the men in the sample of Norwegian-born residents of the United States and in the study groups in Norway additional data have been collected on dietary habits. The items of information that one attempted to obtain for all individuals under study included height and weight. Reasons for considering height and weight were the known and suspected association of body size, as indexed by height, weight, or a function of the two, with morbidity and mortality from a number of diseases and the variation of body size with living conditions and habits of the individuals.

The main objective of this paper is to present the pattern of variation in height, weight, and weight adjusted for height in a cross-section of the adult Norwegian population. For this purpose only the data pertaining to individuals in a probability sample of the general population will be considered.

The index weight divided by the square of height $\left(\mathrm{W} / \mathrm{H}^{2}\right)$, sometimes called the Davenport index, here referred to as the bulk index, was chosen as a simple measure of weight adjusted for height. This is in accordance with Wedervang (Bøe, Humerfelt, and Wedervang, 1957) who, in his analysis of height and weight measurements in the adult population of the city of Bergen, Norway, found that $\left(\mathrm{W} / \mathrm{H}^{2}\right)$ in both males and females was more nearly uncorrelated with height than was either $(\mathrm{W} / \mathrm{H})$ or $\left(\mathrm{W} / \mathrm{H}^{\mathbf{3}}\right)$. Several recent reports have dealt with the choice of indices of bulk, or obesity, derived from height and weight (Khosla and Lowe, 1967; Evans and Prior, 1969; Florey, 1970; Benn, 1971). Florey (1970), who did not control for age, concluded that, based on the criterion that the index for weight adjusted for height should be uncorrelated with height, (W/H) might be better than $\left(W / H^{2}\right)$ in $\overrightarrow{\vec{\omega}}$ western female populations. Consequently, the $\stackrel{S}{S}$ variation of weight $(\mathrm{W} / \mathrm{H})$ and $\left(\mathrm{W} / \mathrm{H}^{2}\right)$, with height $\AA$ within sex and age in our sample will be examined.

Materials AND Methods

The data are derived from questionnaires com- $\overrightarrow{0}$ pleted by respondents to a mail survey in a system- 0 atic sample drawn from the general population of Norway. The questions on height and weight were: $\vec{z}$ 'How tall are you (without shoes)? . . . cm', and 'How much do you weigh (in ordinary clothing)? ... kg'. These questions were incorporated together with a number of other questions, most of them referring to smoking habits and cardiorespiratorg $\vec{\varphi}$ symptoms, in a questionnaire which was completed. by the majority of the respondents during the ear autumn of 1964. Partially or fully completed questionnaires were received from 8,638 men and 10,331 women. The response rates were slightly higher in females $(82 \%)$ than in males $(79 \%)$, and lower in Oslo than in the rest of the country.

The sampling frame was based on persons who at the national census in 1960 were recorded as residents of Norway. It included all men born between 1893 and 1927 and all women born between 1893 and 1932. The sampling fraction was higher for residents of the south-western region (Agder, Rogaland) and the sparsely populated northern-most region (Finnmark) than for the rest of the country. In all regions the sampling fraction was twice as large for persons born between 1893 and 1912 as for persons born after 1912 .

The age grouping used in the tables refers to age at completion of the questionnaire, which was taken as age as of December 31, 1964. The switch o in the sampling fraction with age occurs in the age $N$ group 45-54, thus tending to make the mean ages $N$ in this age group slightly higher than the means in the sampled populations of the various regions. As the focus in this paper is on contrasts within the sample as comparisons between age groups, types of community, occupational groups, and the study of weight/height relationships within relatively 
broad age categories, no need was found for the theoretically desirable weighting according to the varying sampling fractions between strata. Such procedures would have diverged from the mode of presentation of other data from the survey and might seemingly have obscured the relationship to the actual observations. Apart from the statistics based on all ages combined, the means based on unweighted totals would differ only negligibly from appropriately weighted means. When estimates of the precision of domain means are given, they are based on variance estimation appropriate for simple random sampling within those components of the population. In our case of systematic sampling such estimation is believed to be conservative.

An interviewer follow-up of a subsample of nonrespondents showed that many of them had not received the questionnaire because the address was incomplete or for some other reason. Possible biases of the height and weight estimates introduced by this type of non-coverage and the small proportion of non-response among the actual recipients of the questionnaire must be trivial. When it comes to comparisons within the sample, such biases can be ignored.

As interest was in contrasts within the sample, no attempt was made to obtain measurements under standardized conditions of heights and weights in a subsample of the respondents to assess the accuracy of statements on height and weight. A priori, one would expect average stated weight to be higher than nude weight, even though there were indications that some individuals reported nude weight instead of weight in clothing. One might hypothesize, however, that individuals who considered themselves too heavy for their height would tend to understate their weight, or to avoid reporting height or weight or both. Conversely, persons of low weight for height may have overstated their weights. In a different setting, Damon (1965) found that the stated weights of U.S. soldiers regressed towards the mean when compared with their measured weights. Thus, one might construe possible variable biases that could conceivably influence estimates of the mean values, but it is difficult to see how this would invalidate the comparison of group means within sex, except perhaps in the estimation of trends in weight with increasing height.

The mean values, by sex and age, including special tabulations for the city of Bergen, were compared with those reported on the basis of actual measurements of other groups of Norwegian adults (Lindberg, Natvig, Rygh, and Svendsen, 1956; Bøe et al., 1957; Udjus, 1964; Natvig and Vellar, 1965). The value of the information that thus could be derived was restricted by the confounding of the special occupational and regional composition of the latter, and period differences, with the effects of differences in the method of obtaining the height/ weight data. The mail survey data on height seemed to be reasonably in accord with those obtained by actual measurements, when due account is taken of the secular increase in stature (Udjus, 1964; Natvig and Vellar, 1965). The weight data were more difficult to interpret. Although the comparison data for females were scarce, they were consistent with the possibility that females, relative to males, tended to understate their weights. Whatever one's interpretation as to the direction and size of differences between the expectations of the mean values from a series such as ours, and the true values as they would have been represented by actual measurements, such biases dwindle in importance when it comes to the main theme of this paper, viz., the sex-specific contrasts within the series.

\section{WEIGHT BY HeIGHT}

\section{RESULTS}

In the total sample the average weight among the men, 37 to 71 years of age, ranged from $69 \cdot 1 \mathrm{~kg}$ for those $162-165 \mathrm{~cm}$ tall to $86 \cdot 3 \mathrm{~kg}$ for those $186-189$ $\mathrm{cm}$ tall. Among the women, 32 to 71 years of age, the average weight over the equidistant span of height, from $150-153 \mathrm{~cm}$ to $174-177 \mathrm{~cm}$ ranged from $60.1 \mathrm{~kg}$ to $73.7 \mathrm{~kg}$. The variation in mean weight by height within sex and age groups is shown in Figures 1 and 2.

Apart from the fluctuations attributable mainly to sampling error, the slope for the increase in mean weight with increasing height seems to be relatively constant from age group to age group within each sex. The slopes for weight on height in males were only slightly steeper than those in females. Mean

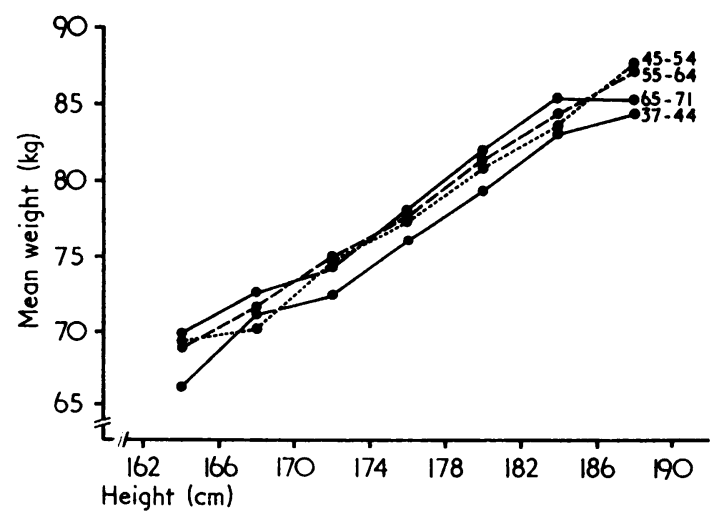

Fig. 1.-Mean weight by height and age in males: Norway, 1964. 


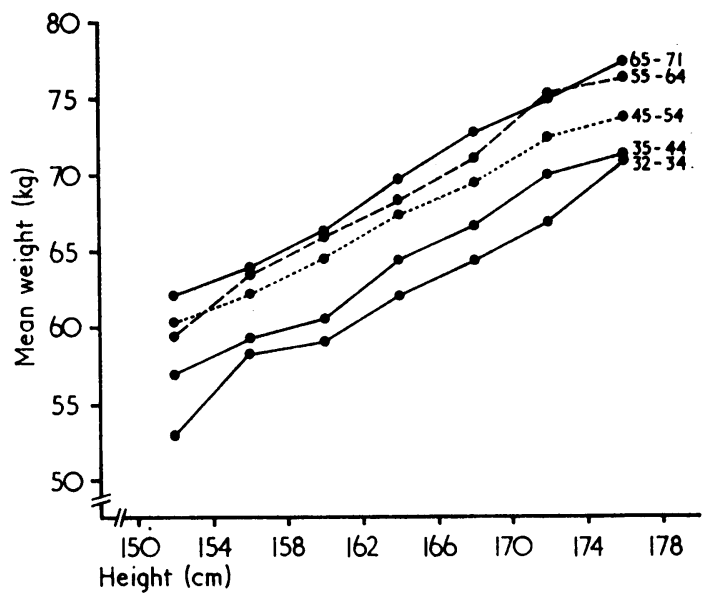

Fig. 2.-Mean weight by height and age in females: Norway, 1964.

weight for given height tended to be lower in men aged 37 to 44 than in older men; there were no appreciable differences between the other age groups. In females, data were available for persons 32 to 36 years of age as well. Figure 2 shows higher weights for given height in females aged 35 to 44 than in those aged 32 to 34 , and markedly higher weights for height in those aged 45 to 54 than in the 35 to $\mathbf{4 4}$ group. In this set of cross-sectional data an increase in weight for given height with increasing age is discernible up to the oldest age group included, the differences being, however, more pronounced between the 32 to 34 and 45 to 54 age groups than between the 45 to 54 and 65 to 71 age groups.

Tables I and II show the means and standard deviations of weight by three broad height groups within the various age groups for males and females respectively. In males the variation in weight, as measured by the standard deviation, increased slightly with increasing height in each age group. When the standard deviation is expressed as per $\stackrel{.}{\Rightarrow}$ cent of the mean, the coefficient of variation, the $\stackrel{\vec{S}}{+}$ dependence on height disappears. In females the $\bar{O}$ standard deviation of weight did not show any 흘 consistent trend with increasing height, so that the $\frac{\bar{\omega}}{T}$

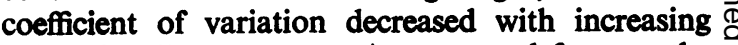
height in all age groups. As a general feature, the variation of the weights, both absolute and relative to the mean weight, was larger in the older age ? groups and larger in females than in the corresponding age-height groups in males.

\section{INDICES FOR WEIGHT ADJUSTED FOR HEIGHT}

The main purpose of Tables I and II is to compare $N$

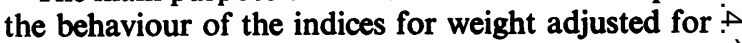
height $(\mathrm{W} / \mathrm{H})$ and $\left(\mathrm{W} / \mathrm{H}^{2}\right)$, with variation in height $\overrightarrow{0}$ by separate age groups within each sex.

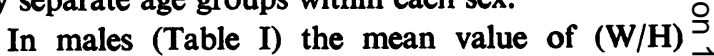
increased with increasing height in all age groups $Z$ considered, the percentage change from the 160-169응 $\mathrm{cm}$ to the $\geqslant 180 \mathrm{~cm}$ height group varying between $\frac{\Phi}{3}$ $7 \cdot 5$ and 9.0. The mean values of $\left(\mathrm{W} / \mathrm{H}^{2}\right)$ were slightly higher in the shortest than in the tallest height groug, the percentage change from the $\geqslant 180 \mathrm{~cm}$ to the $160-169 \mathrm{~cm}$ group varying between 0.4 and 2.4 . …

In females (Table II) the mean value of (W/H) increased with increasing height in all age groups, the percentage change from the $<160 \mathrm{~cm}$ to the $170-179 \mathrm{~cm}$ group varying between $5 \cdot 2$ and $8 \cdot 2$. The mean values of $\left(\mathrm{W} / \mathrm{H}^{2}\right)$ were higher in the shortest $\stackrel{\mathrm{Q}}{\perp}$ than in the tallest height group, the percentage $\overrightarrow{\vec{B}}$ change from the $170-179 \mathrm{~cm}$ to the $<160 \mathrm{~cm}$ group 3 varying between 1.7 and 4.9 .

Within the relatively narrow height categories?

TABLE I

HEIGHT-WEIGHT INDICES BY HEIGHT IN MALES: NORWAY, 1964

\begin{tabular}{|c|c|c|c|c|c|c|c|c|c|}
\hline \multirow{2}{*}{ Age (yr) } & \multirow{2}{*}{ Height (cm) } & \multirow{2}{*}{ No. } & \multirow{2}{*}{ Mean Height } & \multicolumn{2}{|c|}{ Weight (kg) } & \multicolumn{2}{|c|}{$\begin{array}{l}\text { Weight (kg)/ } \\
\text { Height (cm) }\end{array}$} & \multicolumn{2}{|c|}{$\begin{array}{l}\text { Weight (g)/, } \\
\text { Height (cm) }\end{array}$} \\
\hline & & & & Mean & S.D. & Mean & S.D. & Mean & S.D. \\
\hline $37-44$ & $\begin{array}{c}160-169 \\
170-179 \\
\geqslant 180\end{array}$ & $\begin{array}{l}155 \\
855 \\
499\end{array}$ & $\begin{array}{l}167 \\
175 \\
183\end{array}$ & $\begin{array}{l}70.2 \\
75.3 \\
82.9\end{array}$ & $\begin{array}{l}7 \cdot 2 \\
8.0 \\
8.6\end{array}$ & $\begin{array}{l}0.420 \\
0.431 \\
0.452\end{array}$ & $\begin{array}{l}0.042 \\
0.044 \\
0.045\end{array}$ & $\begin{array}{l}2.51 \\
2.47 \\
2.46\end{array}$ & $\begin{array}{l}0.25 \\
0.25 \\
0.24\end{array}$ \\
\hline $45-54$ & $\begin{array}{c}160-169 \\
170-179 \\
\geqslant 180\end{array}$ & $\begin{array}{r}385 \\
1,377 \\
566 \\
\end{array}$ & $\begin{array}{l}166 \\
174 \\
183 \\
\end{array}$ & $\begin{array}{l}69 \cdot 8 \\
76.9 \\
83.7 \\
\end{array}$ & $\begin{array}{l}6.8 \\
8.1 \\
9.3\end{array}$ & $\begin{array}{l}0.420 \\
0.441 \\
0.458 \\
\end{array}$ & $\begin{array}{l}0.041 \\
0.045 \\
0.049\end{array}$ & $\begin{array}{l}2.52 \\
2.53 \\
2.51\end{array}$ & $\begin{array}{l}0.25 \\
0.26 \\
0.27\end{array}$ \\
\hline $55-64$ & $\begin{array}{c}160-169 \\
170-179 \\
\geqslant 180\end{array}$ & $\begin{array}{r}560 \\
1,686 \\
495\end{array}$ & $\begin{array}{l}166 \\
174 \\
183\end{array}$ & $\begin{array}{l}70.3 \\
77.0 \\
84.1\end{array}$ & $\begin{array}{l}7.8 \\
8.6 \\
9.3\end{array}$ & $\begin{array}{l}0.423 \\
0.442 \\
0.460\end{array}$ & $\begin{array}{l}0.046 \\
0.048 \\
0.050\end{array}$ & $\begin{array}{l}2.55 \\
2.54 \\
2.52 \\
\end{array}$ & $\begin{array}{l}0.27 \\
0.27 \\
0.27 \\
\end{array}$ \\
\hline $65-71$ & $\begin{array}{c}160-169 \\
170-179 \\
\geqslant 180\end{array}$ & $\begin{array}{l}375 \\
200 \\
204\end{array}$ & $\begin{array}{l}166 \\
174 \\
182\end{array}$ & $\begin{array}{l}71 \cdot 2 \\
76 \cdot 7 \\
84.1\end{array}$ & $\begin{array}{r}9 \cdot 2 \\
8 \cdot 6 \\
10.2\end{array}$ & $\begin{array}{l}0.429 \\
0.442 \\
0.461\end{array}$ & $\begin{array}{l}0.055 \\
0.048 \\
0.055\end{array}$ & $\begin{array}{l}2.59 \\
2.54 \\
2.53\end{array}$ & $\begin{array}{l}.33 \\
0.27 \\
0.30 \\
\end{array}$ \\
\hline $37-71$ & $\begin{array}{c}160-169 \\
170-179 \\
\geqslant 180\end{array}$ & $\begin{array}{l}1,470 \\
4,720 \\
1,764\end{array}$ & $\begin{array}{l}166 \\
174 \\
183\end{array}$ & $\begin{array}{l}70.4 \\
76.6 \\
83.7\end{array}$ & $\begin{array}{l}7.9 \\
8.4 \\
9.2\end{array}$ & $\begin{array}{l}0.423 \\
0.440 \\
0.457\end{array}$ & $\begin{array}{l}0.047 \\
0.047 \\
0.049\end{array}$ & $\begin{array}{l}2.55 \\
2.52 \\
2.50\end{array}$ & $\begin{array}{l}0.28 \\
0.27 \\
0.27\end{array}$ \\
\hline
\end{tabular}


TABLE II

HEIGHT-WEIGHT INDICES BY HEIGHT IN FEMALES: NORWAY, 1964

\begin{tabular}{|c|c|c|c|c|c|c|c|c|c|}
\hline \multirow{2}{*}{ Age (yr) } & \multirow{2}{*}{ Height (cm) } & \multirow{2}{*}{ No. } & \multirow{2}{*}{ Mean Height } & \multicolumn{2}{|c|}{ Weight (kg) } & \multicolumn{2}{|c|}{$\begin{array}{l}\text { Weight (kg)/ } \\
\text { Height (cm) }\end{array}$} & \multicolumn{2}{|c|}{$\begin{array}{l}\text { Weight (g)/ } \\
\text { Height (cm) }\end{array}$} \\
\hline & & & & Mean & S.D. & Mean & S.D. & Mean & S.D. \\
\hline $32-34$ & $\begin{array}{c}<160 \\
160-169 \\
170-179\end{array}$ & $\begin{array}{r}79 \\
325 \\
85\end{array}$ & $\begin{array}{l}156 \\
164 \\
172\end{array}$ & $\begin{array}{l}56 \cdot 9 \\
62 \cdot 5 \\
67 \cdot 5\end{array}$ & $\begin{array}{l}7 \cdot 3 \\
7 \cdot 7 \\
7 \cdot 5\end{array}$ & $\begin{array}{l}0.365 \\
0.380 \\
0.393\end{array}$ & $\begin{array}{l}0.047 \\
0.046 \\
0.043\end{array}$ & $\begin{array}{l}2 \cdot 34 \\
2 \cdot 32 \\
2 \cdot 28\end{array}$ & $\begin{array}{l}0.31 \\
0.28 \\
0.25\end{array}$ \\
\hline $35-44$ & $\begin{array}{c}<160 \\
160-169 \\
170-179\end{array}$ & $\begin{array}{r}293 \\
1,163 \\
344\end{array}$ & $\begin{array}{l}156 \\
164 \\
172\end{array}$ & $\begin{array}{l}59 \cdot 1 \\
64 \cdot 6 \\
70 \cdot 4\end{array}$ & $\begin{array}{l}8 \cdot 6 \\
8 \cdot 4 \\
8 \cdot 1\end{array}$ & $\begin{array}{l}0.378 \\
0.393 \\
0.409\end{array}$ & $\begin{array}{l}0.055 \\
0.050 \\
0.046\end{array}$ & $\begin{array}{l}2 \cdot 42 \\
2 \cdot 39 \\
2 \cdot 38\end{array}$ & $\begin{array}{l}0.35 \\
0.30 \\
0.27\end{array}$ \\
\hline $45-54$ & $\begin{array}{c}<160 \\
160-169 \\
170-179\end{array}$ & $\begin{array}{r}587 \\
1,485 \\
262\end{array}$ & $\begin{array}{l}156 \\
164 \\
172\end{array}$ & $\begin{array}{l}62 \cdot 6 \\
67 \cdot 5 \\
72 \cdot 6\end{array}$ & $\begin{array}{l}9 \cdot 4 \\
9 \cdot 3 \\
9 \cdot 7\end{array}$ & $\begin{array}{l}0.402 \\
0.411 \\
0.423\end{array}$ & $\begin{array}{l}0.059 \\
0.056 \\
0.057\end{array}$ & $\begin{array}{l}2 \cdot 58 \\
2 \cdot 51 \\
2 \cdot 46\end{array}$ & $\begin{array}{l}0.38 \\
0.34 \\
0.33\end{array}$ \\
\hline $55-64$ & $\begin{array}{c}<160 \\
160-169 \\
170-179\end{array}$ & $\begin{array}{r}868 \\
1,762 \\
268\end{array}$ & $\begin{array}{l}155 \\
164 \\
172\end{array}$ & $\begin{array}{l}63 \cdot 4 \\
68 \cdot 6 \\
75 \cdot 7\end{array}$ & $\begin{array}{r}9.1 \\
9.7 \\
10.5\end{array}$ & $\begin{array}{l}0.408 \\
0.419 \\
0.440\end{array}$ & $\begin{array}{l}0.057 \\
0.058 \\
0.061\end{array}$ & $\begin{array}{l}2 \cdot 62 \\
2 \cdot 56 \\
2 \cdot 56\end{array}$ & $\begin{array}{l}0.37 \\
0.36 \\
0.36\end{array}$ \\
\hline $65-71$ & $\begin{array}{c}<160 \\
160-169 \\
170-179\end{array}$ & $\begin{array}{l}551 \\
868 \\
134\end{array}$ & $\begin{array}{l}155 \\
163 \\
172\end{array}$ & $\begin{array}{l}63.6 \\
69 \cdot 6 \\
75.6\end{array}$ & $\begin{array}{r}10.6 \\
10 \cdot 0 \\
8.7\end{array}$ & $\begin{array}{l}0.411 \\
0.426 \\
0.440\end{array}$ & $\begin{array}{l}0.068 \\
0.060 \\
0.050\end{array}$ & $\begin{array}{l}2.66 \\
2.60 \\
2.56\end{array}$ & $\begin{array}{l}0.45 \\
0.36 \\
0.29\end{array}$ \\
\hline $32-71$ & $\begin{array}{l}<160 \\
160-169 \\
170-179\end{array}$ & $\begin{array}{l}2,378 \\
5,568 \\
1,093\end{array}$ & $\begin{array}{l}155 \\
164 \\
172\end{array}$ & $\begin{array}{l}62 \cdot 5 \\
67 \cdot 3 \\
72 \cdot 7\end{array}$ & $\begin{array}{l}9 \cdot 6 \\
9 \cdot 5 \\
9 \cdot 5\end{array}$ & $\begin{array}{l}0.402 \\
0.410 \\
0.423\end{array}$ & $\begin{array}{l}0.061 \\
0.057 \\
0.055\end{array}$ & $\begin{array}{l}2 \cdot 59 \\
2 \cdot 51 \\
2.46\end{array}$ & $\begin{array}{l}0.40 \\
0.35 \\
0.32\end{array}$ \\
\hline
\end{tabular}

studied, the predominant source of variation of the two indices is the numerator, i.e. weight. Thus, it is not surprising that the coefficient of variation for each of the two indices was very close to the coefficient of variation of weight in all sex, age, and height categories, displaying the same pattern of variation that was described for weight.

In summary, the percentage change between the two extreme height categories was smaller for $\left(\mathrm{W} / \mathrm{H}^{2}\right)$ than for $(\mathrm{W} / \mathrm{H})$ in all sex-age groups. Consequently, based on the criterion that the index for weight adjusted for height should be uncorrelated with height, one must conclude that $\left(\mathrm{W} / \mathrm{H}^{2}\right)$ is preferable to $(\mathrm{W} / \mathrm{H})$ for both males and females in the present series.

A feature, which is not evident in the male data, is displayed by the data for females. In all age groups combined, i.e., the total 32 to 71 years age group, the percentage change from one extreme height group to another was less pronounced for $(\mathrm{W} / \mathrm{H})$ than in any individual age group (apart from the 45 to 54 years group where it was identical), and more pronounced for $\left(\mathrm{W} / \mathrm{H}^{2}\right)$ than in any individual age group. Thus, while the percentage change in the mean value of the index from the height group with the lowest value of the index to the other extreme height group in all individual age groups was larger for $(W / H)$ than for $\left(W / H^{2}\right)$, this difference disappeared in the total group where the changes were 5.2 and $5.3 \%$ respectively. These phenomena, of an attenuation of a positive correlation and a strengthening of a negative correlation between two variables, are both due to the pooling of age groups which are heterogeneous with respect to both variables, and which change in opposite directions with age. The one variable, height, decreased with increasing age in both sexes. In females, but not perceptibly so in males, both indices increased with increasing age.

\section{Height-weight BY TYPE OF COMMUNTY}

Tables III and IV give the sex- and age-specific means for height and the bulk index $\left(\mathrm{W} / \mathrm{H}^{2}\right)$, by region of residence at the time of the 1960 census, which for most respondents coincided with their region of residence at the time of the survey. By reading the rows of the tables across regions one obtains, apart from Oslo and the east region, a ranking of the regions according to latitude, from the south-western region of Agder, Rogaland to Finnmark in the north-east.

In both sexes there was a decrease in mean height from the younger to the older age groups, evident for all regions. Only females 32 to 34 years of age departed from the consistency of this trend. Although one should allow for relatively large sampling errors due to the small size of this group, the overall tendency for the 32 to 34 years age group is clearly to break the pattern of a steady decrease in height with age. Residents of Oslo were slightly taller than the national average and those of the two northernmost regions were clearly shorter, the lowest mean heights being observed for Finnmark.

The mean heights in Table III reflect closely the variation in height associated with region of birth in those who in 1960 were living in their county of birth. Within a region, mean heights could, however,

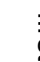


TABLE III

MEAN HEIGHT (CM), BY SEX, AGE, AND REGION OF RESIDENCE: 8,120 MEN AND 9,180 WOMEN, NORWAY, 1964

\begin{tabular}{|c|c|c|c|c|c|c|c|c|}
\hline \multirow{2}{*}{$\begin{array}{l}\text { Sex and } \\
\text { Age (yr) }\end{array}$} & \multicolumn{7}{|c|}{ Region of Residence as of 1960} & \multirow[b]{2}{*}{$\begin{array}{l}\text { Whole } \\
\text { Country }\end{array}$} \\
\hline & Oslo & East & $\begin{array}{c}\text { Agder, } \\
\text { Rogaland }\end{array}$ & West & Trøndelag & $\begin{array}{l}\text { Nordland, } \\
\text { Troms }\end{array}$ & Finnmark & \\
\hline $\begin{array}{l}\text { Males: } \\
37-44 \\
45-54 \\
55-64 \\
65-71\end{array}$ & $\begin{array}{l}177.9 \\
176.4 \\
174.3 \\
173.6\end{array}$ & $\begin{array}{l}177 \cdot 0 \\
175 \cdot 3 \\
173 \cdot 4 \\
172 \cdot 5\end{array}$ & $\begin{array}{l}177 \cdot 1 \\
175 \cdot 1 \\
174 \cdot 7 \\
172 \cdot 8\end{array}$ & $\begin{array}{l}176.9 \\
174 \cdot 4 \\
173 \cdot 5 \\
171.9\end{array}$ & $\begin{array}{l}175.6 \\
175.4 \\
173.4 \\
173.6\end{array}$ & $\begin{array}{l}176 \cdot 4 \\
173 \cdot 7 \\
173 \cdot 7 \\
170.9\end{array}$ & $\begin{array}{l}173.9 \\
171.6 \\
169.6 \\
169.2\end{array}$ & $\begin{array}{l}176 \cdot 8 \\
175 \cdot 0 \\
173 \cdot 8 \\
172 \cdot 4\end{array}$ \\
\hline $37-71$ & $175 \cdot 4$ & $174 \cdot 5$ & 174.9 & $174 \cdot 1$ & $174 \cdot 4$ & $173 \cdot 7$ & $171 \cdot 0$ & $174 \cdot 4$ \\
\hline $\begin{array}{l}\text { Females: } \\
32-34 \\
35-44 \\
45-54 \\
55-64 \\
65-71\end{array}$ & $\begin{array}{l}165.9 \\
165 \cdot 3 \\
163 \cdot 4 \\
162 \cdot 8 \\
161.9\end{array}$ & $\begin{array}{l}164 \cdot 6 \\
164.8 \\
163 \cdot 0 \\
162 \cdot 0 \\
160.9\end{array}$ & $\begin{array}{l}164 \cdot 7 \\
164 \cdot 7 \\
163 \cdot 3 \\
162 \cdot 2 \\
161 \cdot 6\end{array}$ & $\begin{array}{l}163.9 \\
164 \cdot 7 \\
162 \cdot 8 \\
161 \cdot 7 \\
160 \cdot 6\end{array}$ & $\begin{array}{l}164.4 \\
164.6 \\
162.5 \\
161.8 \\
160.9\end{array}$ & $\begin{array}{l}164 \cdot 2 \\
163 \cdot 6 \\
162 \cdot 0 \\
160.9 \\
160.7\end{array}$ & $\begin{array}{l}161 \cdot 0 \\
161.6 \\
160.5 \\
159.0 \\
158.5\end{array}$ & $\begin{array}{l}164 \cdot 4 \\
164 \cdot 6 \\
162 \cdot 9 \\
161 \cdot 9 \\
161 \cdot 1\end{array}$ \\
\hline $32-71$ & $163 \cdot 3$ & $162 \cdot 8$ & 163.0 & $162 \cdot 4$ & $162 \cdot 5$ & $161 \cdot 9$ & $160 \cdot 1$ & $162 \cdot 7$ \\
\hline
\end{tabular}

TABLE IV

MEAN BULK INDEX, WEIGHT (g)/ HEIGHT (cm) ' BY SEX, AGE, AND REGION OF RESIDENCE: 8,031 MEN AND 9,056 WÓMEN, NORWAY, 1964

\begin{tabular}{|c|c|c|c|c|c|c|c|c|}
\hline \multirow{2}{*}{$\begin{array}{l}\text { Sex and } \\
\text { Age (yr) }\end{array}$} & \multicolumn{7}{|c|}{ Region of Residence as of 1960} & \multirow{2}{*}{$\begin{array}{l}\text { Whole } \\
\text { Country }\end{array}$} \\
\hline & Oslo & East & $\begin{array}{l}\text { Agder, } \\
\text { Rogaland }\end{array}$ & West & Trøndelag & $\begin{array}{c}\text { Nordland, } \\
\text { Troms }\end{array}$ & Finnmark & \\
\hline $\begin{array}{l}\text { Males: } \\
37-44 \\
45-54 \\
55-64 \\
65-71\end{array}$ & $\begin{array}{l}2.44 \\
2.51 \\
2.51 \\
2.52\end{array}$ & $\begin{array}{l}2.47 \\
2.51 \\
2.54 \\
2.56\end{array}$ & $\begin{array}{l}2 \cdot 48 \\
2 \cdot 51 \\
2 \cdot 53 \\
2.54\end{array}$ & $\begin{array}{l}2.49 \\
2.53 \\
2.55 \\
2.55\end{array}$ & $\begin{array}{l}2 \cdot 46 \\
2 \cdot 59 \\
2 \cdot 58 \\
2 \cdot 57\end{array}$ & $\begin{array}{l}2 \cdot 46 \\
2 \cdot 54 \\
2 \cdot 57 \\
2 \cdot 61\end{array}$ & $\begin{array}{l}2 \cdot 49 \\
2 \cdot 55 \\
2.55 \\
2.53\end{array}$ & $\begin{array}{l}2.47 \\
2.52 \\
2.54 \\
2.55\end{array}$ \\
\hline $37-71$ & $2 \cdot 50$ & $2 \cdot 52$ & $2 \cdot 52$ & $2 \cdot 53$ & $2 \cdot 56$ & $2 \cdot 55$ & $2 \cdot 53$ & $2 \cdot 52$ \\
\hline $\begin{array}{l}\text { Females: } \\
32-34 \\
35-44 \\
45-54 \\
55-64 \\
65-71\end{array}$ & $\begin{array}{l}2 \cdot 18 \\
2 \cdot 32 \\
2 \cdot 39 \\
2 \cdot 49 \\
2 \cdot 53\end{array}$ & $\begin{array}{l}2 \cdot 34 \\
2 \cdot 41 \\
2 \cdot 52 \\
2 \cdot 59 \\
2 \cdot 65\end{array}$ & $\begin{array}{l}2 \cdot 30 \\
2 \cdot 39 \\
2 \cdot 52 \\
2 \cdot 59 \\
2 \cdot 63\end{array}$ & $\begin{array}{l}2 \cdot 34 \\
2 \cdot 40 \\
2 \cdot 54 \\
2 \cdot 58 \\
2 \cdot 58\end{array}$ & $\begin{array}{l}2.39 \\
2.43 \\
2.57 \\
2.63 \\
2.65\end{array}$ & $\begin{array}{l}2 \cdot 34 \\
2 \cdot 44 \\
2 \cdot 58 \\
2 \cdot 60 \\
2 \cdot 65\end{array}$ & $\begin{array}{l}2 \cdot 31 \\
2 \cdot 34 \\
2 \cdot 63 \\
2 \cdot 67 \\
2 \cdot 67\end{array}$ & $\begin{array}{l}2 \cdot 31 \\
2 \cdot 39 \\
2 \cdot 52 \\
2 \cdot 58 \\
2 \cdot 62\end{array}$ \\
\hline $32-71$ & $2 \cdot 43$ & $2 \cdot 53$ & $2 \cdot 52$ & $2 \cdot 52$ & $2 \cdot 57$ & $2 \cdot 55$ & $2 \cdot 56$ & $2 \cdot 52$ \\
\hline
\end{tabular}

differ appreciably between those who were living in their county of birth and those who were not. For the country as a whole males living in the same county as that of their birth were slightly shorter than those living in a different county. This difference was found in all age groups. In females, however, such a difference did not show up in all age groups and was only barely suggested by the data for all age groups combined.

In spite of the above-average heights shown for Oslo in Table III, there were only minor differences between densely populated and sparsely populated areas when height was studied in relation to the type of municipality of current residence. The fact that mean heights were smaller in fishing areas, which are concentrated in the northern regions, only serves to illustrate the general finding that height was much more closely associated with the geographic region than any other characteristic of the municipality.
Mean weight, irrespective of height, in males showed a decrease with age within the age range ${ }_{\odot}^{\infty}$ studied. In females weight increased with age. The mean values of the bulk index are shown in Table 3 . IV. The index increased with increasing age in both sexes, but considerably more in females than in 3 males. Thus, the ratio of the mean index in males over that in females changed from being greater than one before age 45 to 54 years to being less than one after this age.

The index behaved differently in married and $\tilde{N}$ single persons. Figure 3, which gives the different rates of increase in bulk with increasing age in theN two sexes, shows the increasing differential in bulk ${ }_{O}^{\omega}$ between married and single women as age progresses. One notes that average bulk in the married? did not exceed that for the never married in thees youngest age groups, and that the ratio between the two in both sexes was higher at ages 55 to 71 than 


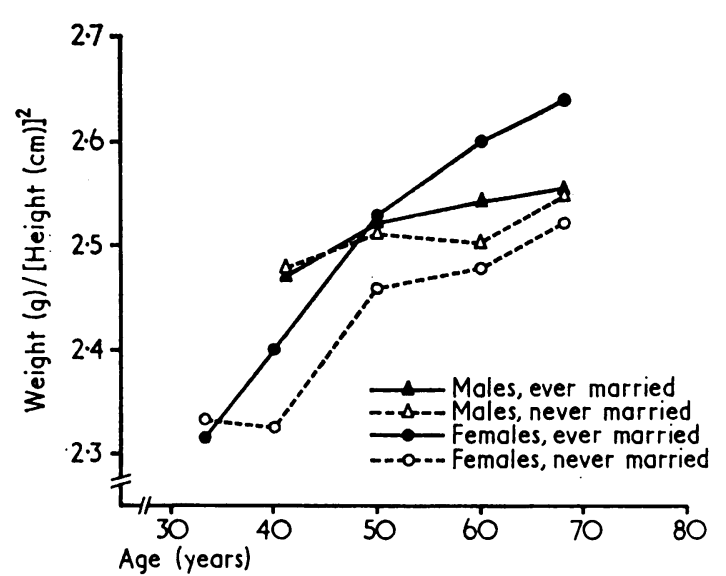

Fig. 3.-Mean bulk index, Weight (g)/ Height $(\mathrm{cm})^{2}$, by sex, age, and marital status: Norway, 1964.

in the 45 to 54 years age group. Differences in males according to marital status were small.

In both sexes the highest values for the bulk index were found for the Trøndelag region; the lowest and the most divergent values were those for the city of Oslo. The mean values in Table $\mathrm{V}$ follow closely those obtained by persons born in those regions and in 1960 living in their county of birth. However, there was a clear tendency in females, but not in males, for those who were living in a county different from that of their birth, to be less bulky.

In Table $\mathrm{V}$, the bulk index is shown by the type of municipality in 1960. The classification denotes densely populated areas other than towns and suburbs, and sparsely populated areas, according to the characteristic occupational pattern among the economically active population. As was illustrated by the data for Oslo (Table IV), the bulk index was lower in densely populated areas than in sparsely populated areas. Among the latter there was no difference between areas characterized by agriculture and forestry and the fishing areas. The variation with type of municipality was more pronounced in females than in males. The pattern of less bulk in densely populated than in sparsely populated areas was seen in each sex for all regions in which the classification was applicable.

An example of a joint classification of the individuals by characteristics of their birthplace and current residence is shown in Table VI. By employing the same classification and coding practices for birthplace and place of residence in 1960, which in general coincided with current place, these places were classified as either urban or rural. In each sex persons born in rural areas had a higher bulk index than those born in urban areas, irrespective of urbanization of current place. Conversely, persons living in rural areas had a higher bulk index than those living in urban areas irrespective of urbanization of their birthplace. In general, the most pronounced differences were found between those born in, and in 1960 still living in, rural communities and those born in, and in 1960 still living in, urban communities. The association of bulk with urban/ rural characterization of the community was somewhat stronger in males for birthplace than for current place. In females the association with current place was the strongest, the association with birthplace being evident mainly in the younger age groups.

\section{Height-weight By Occupation}

For the male respondents statements on longest occupation ever had were coded to occupational group according to a scheme used by the Central Bureau of Statistics of Norway (Norway's Official

TABLE V

MEAN BULK INDEX, WEIGHT (g)/ HEIGHT (cm $)^{2}$, BY SEX, AGE, AND TYPE OF MUNICIPALITY: NORWAY, 1964

\begin{tabular}{|c|c|c|c|c|c|c|c|c|}
\hline $\begin{array}{l}\text { Sex and } \\
\text { Age (yr) }\end{array}$ & Towns & Suburbs & Industrial & $\begin{array}{c}\text { Other } \\
\text { Densely } \\
\text { Populated }\end{array}$ & $\begin{array}{c}\text { Agricultural } \\
\text { and } \\
\text { Forestry }\end{array}$ & Fishing & $\begin{array}{c}\text { Other } \\
\text { Sparsely } \\
\text { Populated }\end{array}$ & $\begin{array}{l}\text { Whole } \\
\text { Country }\end{array}$ \\
\hline $\begin{array}{l}\text { Males: } \\
37-44 \\
45-54 \\
55-64 \\
65-71\end{array}$ & $\begin{array}{l}2.44 \\
2.49 \\
2 \cdot 50 \\
2.52\end{array}$ & $\begin{array}{l}2 \cdot 44 \\
2 \cdot 52 \\
2 \cdot 54 \\
2 \cdot 58\end{array}$ & $\begin{array}{l}2 \cdot 47 \\
2 \cdot 50 \\
2 \cdot 51 \\
2 \cdot 55\end{array}$ & $\begin{array}{l}2 \cdot 47 \\
2 \cdot 57 \\
2 \cdot 55 \\
2 \cdot 57\end{array}$ & $\begin{array}{l}2 \cdot 51 \\
2 \cdot 53 \\
2 \cdot 55 \\
2 \cdot 55\end{array}$ & $\begin{array}{l}2 \cdot 48 \\
2.55 \\
2.58 \\
2.58\end{array}$ & $\begin{array}{l}2 \cdot 51 \\
2 \cdot 55 \\
2 \cdot 56 \\
2 \cdot 58\end{array}$ & $\begin{array}{l}2 \cdot 47 \\
2 \cdot 52 \\
2 \cdot 54 \\
2 \cdot 55\end{array}$ \\
\hline $37-71$ & 2.49 & 2.52 & 2.51 & $2 \cdot 54$ & 2.54 & 2.55 & 2.55 & 2.52 \\
\hline $\begin{array}{l}\text { Females: } \\
32-34 \\
35-44 \\
45-54 \\
55-64 \\
65-71\end{array}$ & $\begin{array}{l}2 \cdot 24 \\
2 \cdot 33 \\
2 \cdot 43 \\
2 \cdot 53 \\
2 \cdot 55\end{array}$ & $\begin{array}{l}2 \cdot 26 \\
2 \cdot 37 \\
2 \cdot 53 \\
2 \cdot 55 \\
2 \cdot 59\end{array}$ & $\begin{array}{l}2 \cdot 30 \\
2 \cdot 40 \\
2 \cdot 50 \\
2 \cdot 59 \\
2 \cdot 65\end{array}$ & $\begin{array}{l}2 \cdot 41 \\
2 \cdot 40 \\
2.53 \\
2.58 \\
2 \cdot 71\end{array}$ & $\begin{array}{l}2.38 \\
2.49 \\
2.60 \\
2.65 \\
2.66\end{array}$ & $\begin{array}{l}2 \cdot 45 \\
2 \cdot 42 \\
2 \cdot 62 \\
2 \cdot 61 \\
2 \cdot 69\end{array}$ & $\begin{array}{l}2 \cdot 36 \\
2 \cdot 45 \\
2 \cdot 57 \\
2 \cdot 64 \\
2 \cdot 67\end{array}$ & $\begin{array}{l}2 \cdot 31 \\
2 \cdot 39 \\
2 \cdot 52 \\
2 \cdot 58 \\
2 \cdot 62\end{array}$ \\
\hline $32-71$ & 2.46 & $2 \cdot 48$ & 2.52 & 2.54 & 2.59 & $2 \cdot 58$ & $2 \cdot 57$ & 2.52 \\
\hline
\end{tabular}


Statistics, 1964). Data for only broad occupational groups are shown in Table VII. The pattern of variation of the mean values would be only minimally influenced by the modest differences between the age distributions of the groups. The occupational groups varied in size, some being relatively small, so that consideration of the random sampling error of the estimators, as indexed by their standard error, becomes important.

Men in professional and business occupations had heights above average. The large group, 'manufacturing, etc.', comprising manual workers in various industries which, as the former, are concentrated in urban areas, did not, however, exceed the national average. Regional differences in height may to some extent be confounded with occupational associations. Thus, for example, the short stature of men in 'agriculture, forestry, fishing, and related work' could be accounted for partly by a preponderance of men from the northern-most regions.

The variation of the bulk index by the broat occupational groups shown in Table VII reflect the association already demonstrated with such come munity characteristics as density of population an urbanization. There does not seem to be a clearcu类 association of bulk with occupation in a socio economic dimension. Thus, the combination of the groups in Table VII into professional, business, and clerical occupations (code nos. 0-3) and manuat workers (code nos. 4-8) produces only minima $\vec{w}$ differences in bulk between these two main groupsMen in 'manufacturing, etc.' are closer to the group of men in professional, business, and clericah occupations (code nos. 0-3) with respect to bulk than they are to other manual workers.

The broad grouping in Table VII covers up more

TABLE VI

MEAN BULK INDEX, WEIGHT (g)/ HEIGHT (cm) 2', BY SEX, AGE, AND URBAN/RURAL DESIGNATION OF MUNICIPALITY OF BIRTH AND OF RESIDENCE IN 1960: NORWAY, 1964

\begin{tabular}{|c|c|c|c|c|c|c|}
\hline \multirow{3}{*}{ Age (yr) } & \multirow{3}{*}{ Place of Birth } & \multicolumn{5}{|c|}{ Residence in 1960} \\
\hline & & \multicolumn{2}{|c|}{ Male } & \multicolumn{2}{|c|}{ Female } & \\
\hline & & Urban & Rural & Urban & Rural & \\
\hline $32-34$ & $\begin{array}{l}\text { Urban } \\
\text { Rural }\end{array}$ & - & - & $\begin{array}{l}2 \cdot 23 \\
2 \cdot 27\end{array}$ & $\begin{array}{l}2 \cdot 21 \\
2 \cdot 38\end{array}$ & స्रें \\
\hline $35-44 *$ & $\begin{array}{l}\text { Urban } \\
\text { Rural }\end{array}$ & $\begin{array}{l}2.43 \\
2.45\end{array}$ & $\begin{array}{l}2.45 \\
2.49\end{array}$ & $\begin{array}{l}2 \cdot 34 \\
2 \cdot 33 \\
\end{array}$ & $\begin{array}{l}2 \cdot 35 \\
2 \cdot 43\end{array}$ & \\
\hline $45-54$ & $\begin{array}{l}\text { Urban } \\
\text { Rural }\end{array}$ & $\begin{array}{l}2.46 \\
2.53\end{array}$ & $\begin{array}{l}2.48 \\
2 \cdot 54 \\
\end{array}$ & $\begin{array}{l}2 \cdot 39 \\
2 \cdot 48 \\
\end{array}$ & $\begin{array}{l}2 \cdot 53 \\
2 \cdot 58 \\
\end{array}$ & (1) \\
\hline $55-64$ & $\begin{array}{l}\text { Urban } \\
\text { Rural }\end{array}$ & $\begin{array}{l}2.48 \\
2 \cdot 55 \\
\end{array}$ & $\begin{array}{l}2.55 \\
2.56\end{array}$ & $\begin{array}{l}2 \cdot 54 \\
2 \cdot 53 \\
\end{array}$ & $\begin{array}{l}2 \cdot 57 \\
2.62\end{array}$ & $\bar{c}$ \\
\hline $65-71$ & $\begin{array}{l}\text { Urban } \\
\text { Rural }\end{array}$ & $\begin{array}{l}2 \cdot 46 \\
2 \cdot 59\end{array}$ & $\begin{array}{l}2 \cdot 56 \\
2 \cdot 58\end{array}$ & $\begin{array}{l}2.56 \\
2.56\end{array}$ & $\begin{array}{l}2.65 \\
2.67 \\
\end{array}$ & \\
\hline All ages* & $\begin{array}{l}\text { Urban } \\
\text { Rural }\end{array}$ & $\begin{array}{l}2 \cdot 47 \\
2 \cdot 53\end{array}$ & $\begin{array}{l}2 \cdot 51 \\
2 \cdot 54\end{array}$ & $\begin{array}{l}2 \cdot 46 \\
2 \cdot 47\end{array}$ & $\begin{array}{l}2 \cdot 49 \\
2 \cdot 56\end{array}$ & \\
\hline
\end{tabular}

-No males were less than 37 years of age

TABLE VII

MEANS AND STANDARD ERRORS (S.E.) FOR HEIGHT, WEIGHT, AND BULK INDEX IN MEN AGED 37-71 YEARS BY LONGEST OCCUPATION EVER HAD: NORWAY, 1964

\begin{tabular}{|c|c|c|c|c|c|c|}
\hline \multirow{2}{*}{ Occupational Group } & \multicolumn{2}{|c|}{ Height (cm) } & \multicolumn{2}{|c|}{ Weight (kg) } & \multicolumn{2}{|c|}{$\begin{array}{c}\text { Bulk Index, Weight (g)/ } \\
\text { Height (cm) }\end{array}$} \\
\hline & Mean & S.E. & Mean & S.E. & Mean & S.E. \\
\hline $\begin{array}{l}\text { 0. Technical, physical, science, } \\
\text { humanistic, and artistic } \\
\text { 1. Administrative, executive } \\
\text { 2. Clerical } \\
\text { 3. Sales } \\
\text { 4. Agriculture, forestry, fishing, and }\end{array}$ & $\begin{array}{l}176.4 \\
176.2 \\
176.0 \\
175.6\end{array}$ & $\begin{array}{l}0.3 \\
0.5 \\
0.3 \\
0.3\end{array}$ & $\begin{array}{l}77 \cdot 2 \\
78 \cdot 7 \\
76 \cdot 5 \\
77 \cdot 3\end{array}$ & $\begin{array}{l}0.4 \\
0.7 \\
0.5 \\
0.5\end{array}$ & $\begin{array}{l}2.48 \\
2.54 \\
2.47 \\
2.51\end{array}$ & $\begin{array}{l}0.01 \\
0.02 \\
0.01 \\
0.02\end{array}$ \\
\hline $\begin{array}{l}\text { 5. Mining and quarrying } \\
\text { 6. Transport and communication } \\
\text { 7-8. Manufacturing, etc. } \\
\text { Other and not specified }\end{array}$ & $\begin{array}{l}173 \cdot 8 \\
173 \cdot 8 \\
174 \cdot 7 \\
174 \cdot 1 \\
174 \cdot 4\end{array}$ & $\begin{array}{l}0 \cdot 1 \\
0 \cdot 8 \\
0 \cdot 2 \\
0 \cdot 1 \\
0 \cdot 3\end{array}$ & $\begin{array}{l}77 \cdot 0 \\
78 \cdot 3 \\
77 \cdot 9 \\
76 \cdot 1 \\
76 \cdot 8\end{array}$ & $\begin{array}{l}0 \cdot 2 \\
1 \cdot 5 \\
0 \cdot 3 \\
0 \cdot 2 \\
0 \cdot 5\end{array}$ & $\begin{array}{l}2 \cdot 55 \\
2 \cdot 58 \\
2 \cdot 55 \\
2 \cdot 51 \\
2 \cdot 53\end{array}$ & $\begin{array}{l}0.01 \\
0.04 \\
0.01 \\
0.01 \\
0.01\end{array}$ \\
\hline Total & $174 \cdot 4$ & $0 \cdot 1$ & $76 \cdot 8$ & $0 \cdot 1$ & $2 \cdot 52$ & 0.00 \\
\hline
\end{tabular}


pronounced differences in bulk between men in various occupations. Thus, mean bulk index (standard error in parentheses) was as low as 2.41 $(0.02)$ for physicians and dentists; for commercial travellers and agents it was 2.61 (0.04), and for ship's officers it was as high as $2.64(0.03)$. With respect to the latter it is of interest to note that the other group of seamen, deck and engine-room crew, had a mean of $2.53(0.02)$, i.e., very close to the national average. The two groups of seamen did not differ with respect to height, nor did they differ noticeably with respect to age.

\section{BulK INDEX AND OTHER CHARACTERISTICS}

Table VIII shows the mean values of the bulk index by sex, age, and reported cigarette smoking habits. In both sexes the highest bulk values were shown by non-smokers. Among the non-smokers previous smokers were less bulky than those who had never smoked cigarettes, but more bulky than current smokers in all sex and age categories. Among the current smokers there was no clear relationship between bulk and amount smoked. The differences in bulk between current cigarette smokers and those who had never smoked were greater in females than in males, and were greater in old persons than in young persons in both sexes. Thus, in contrast to the total series, among current cigarette smokers the mean bulk index was higher in men than in women in all age groups examined; the index was not higher in older men than in the younger men, and in women the 'increase' with age was considerably less than for the total series with values for those aged 55 to 71 lower than were found in any urban/ rural or regional category.

The bulk index was negatively associated with stated amount of physical exercise in both sexes, the major part of the gradient being observed between those reporting no exercise and those reporting exercise of any degree from slight to heavy. The mean value of the index was 2.57 in males reporting no physical exercise as against 2.52 in those reporting at least slight physical exercise. In females the corresponding figures were $2 \cdot 61$ and 2.49 .

\section{Discussion}

The main emphasis in this paper is on the comparison of averages for various subclasses of the study population and on the relationships thus evidenced between height-weight and other characteristics of the individuals. The geographic coverage and the representativeness of this series of data for the adult population of Norway offer a unique opportunity for valid comparisons with respect to such variables as area of residence, residential history, and occupational group. The data on height and weight were based on statements by respondents to a postal questionnaire. Heightweight data were elicited by the same methods for probability samples of the British and the U.S. native-born populations (Pearl, Levine, and Gerson, 1966; Reid, 1966), thus allowing future comparisons of height-weight levels obtained by similar methods in these countries.

The bulk index, weight divided by the square of height, was used for the purpose of presenting the weight data with a simple adjustment for height. The index, which unavoidably is influenced by muscularity and bone structure, has been shown to correlate fairly well with relative adiposity as estimated from body-density measurements (Billewicz, Kemsley, and Thomson, 1962), fat mass estimated from total body water measurements (Edwards and Whyte, 1962), and the more indirect method of skinfold measurements (Whyte, 1965; Evans and Prior, 1969; Florey, 1970). In such evaluation of the bulk index its association with a true measure of adiposity tends to be attenuated due

TABLE VIII

MEAN BULK INDEX, WEIGHT (g)/ HEIGHT (cm) 2, BY SEX, AGE, AND CURRENT CIGARETTE SMOKING HABITS: NORWAY, 1964

\begin{tabular}{|c|c|c|c|c|c|}
\hline \multirow{2}{*}{ Sex and Age (yr) } & \multicolumn{4}{|c|}{ Cigarette Smoking Habit } & \multirow{2}{*}{ Total } \\
\hline & 1-9/day & $\geqslant 10 /$ day & Ex-smoker & Never Smoked & \\
\hline $\begin{array}{l}\text { Males: } \\
37-44 \\
45-54 \\
55-64 \\
65-71 \\
37-71\end{array}$ & $\begin{array}{l}2.46 \\
2.49 \\
2.54 \\
2.48 \\
2.50\end{array}$ & $\begin{array}{l}2 \cdot 46 \\
2.50 \\
2.50 \\
2.46 \\
2.49\end{array}$ & $\begin{array}{l}2.47 \\
2.54 \\
2.54 \\
2.58 \\
2.53\end{array}$ & $\begin{array}{l}2.49 \\
2.55 \\
2.56 \\
2.57 \\
2.55\end{array}$ & $\begin{array}{l}2.47 \\
2.52 \\
2.54 \\
2.55 \\
2.52\end{array}$ \\
\hline $\begin{array}{l}\text { Females: } \\
32-34 \\
35-44 \\
45-54 \\
55-64 \\
65-71 \\
32-71\end{array}$ & $\begin{array}{l}2.32 \\
2.34 \\
2.45 \\
2.45 \\
2.45 \\
2.40\end{array}$ & $\begin{array}{l}2 \cdot 22 \\
2 \cdot 35 \\
2 \cdot 40 \\
2 \cdot 48 \\
2 \cdot 47 \\
2 \cdot 39\end{array}$ & $\begin{array}{l}2 \cdot 31 \\
2 \cdot 40 \\
2 \cdot 47 \\
2 \cdot 55 \\
2 \cdot 62 \\
2 \cdot 46\end{array}$ & $\begin{array}{l}2.33 \\
2.42 \\
2.55 \\
2.61 \\
2.63 \\
2.56\end{array}$ & $\begin{array}{l}2.31 \\
2.39 \\
2.52 \\
2.58 \\
2.62 \\
2.52\end{array}$ \\
\hline
\end{tabular}


to measurement errors of the reference methods and their unknown validity as measures of body fat (Edwards and Whyte, 1962). Seltzer, Stoudt, Bell, and Mayer (1970) criticized the use of relative body weight and other height-weight designations instead of skinfold measurements to assess obesity. From the association of relative body weight values and skinfold measurements observed in their series of adult males selected from U.S. Army Veterans for their high levels of health they concluded that the highest relative body weight categories were poor indicators of obesity. The strength of the observed association must, however, have been influenced by the sparsity of obese persons in their study. The authors emphasized the important point that weight standardized by height, as an index of fatness, is confounded by body build structure. However, the same applies to the use of skinfold thickness as a measure of fatness when no account is taken of body size (Ruffer, 1970) which explains the high power of below average relative weights in identifying individuals with below average skinfold thickness observed by Seltzer and others (1970).

Since relative adiposity appears to be uncorrelated with height (Billewicz and others, 1962), an index of adiposity derived from height and weight should, in addition to being highly correlated with weight, be uncorrelated with height (Khosla and Lowe, 1967). The finding in the present series that the bulk index $\left(\mathrm{W} / \mathrm{H}^{2}\right)$, when controlled for age, both in men and women, was more nearly uncorrelated with height than was the index $(\mathrm{W} / \mathrm{H})$, conforms with reports by Bøe and others (1957), Billewicz and others (1962), and Evans and Prior (1969), which concluded that $\left(\mathrm{W} / \mathrm{H}^{2}\right)$, based on this criterion, was preferable to both $(\mathrm{W} / \mathrm{H})$ and $\left(\mathrm{W} / \mathrm{H}^{3}\right)$ or $\left(\mathrm{H} / \mathrm{W}^{1 / 3}\right)$. That Florey (1970) did not observe a lower correlation with height for the index $\left(\mathrm{W} / \mathrm{H}^{2}\right)$ than for $(\mathrm{W} / \mathrm{H})$ in his series of North American women might, at least in part, be due to his failure to take the age of the individuals into account. Data from the Health Examination Survey in the United States (Stoudt, Damon, McFarland, and Roberts, 1965) suggest that the associations between the two indices and height in Florey's series would be similarly influenced by the confounding variable, age, as they were in the present series.

With one exception, the present data are consistent with a secular increase in stature. The youngest women, those 32 to 34 years old at the time of the survey, were not taller than those aged 35 to 44 years. Sampling error and the possibility of various response and non-response biases may be appealed to, but the observation may more readily be explained as reflecting a real deviation in the popula- tion from a general trend, attributable to the effect of the war on height attained. Data for Oslo schoolchildren (Baklund, 1962) show that the steady secular increase in average height was halted duringes the years 1940-45, and that the trends in averageo height for the various age groups less than 150 actually declined during those years in both sexes. The women who were 32 to 34 years old at the timed of our survey were 7 to 10 years of age in 1940, ando so young enough to have had their adolescent $t_{-}^{\text {s }}$ growth spurts curtailed during the war.

A variation of height with socio-economic condi- $-\vec{\omega}$ tions is apparent from the height differences by occupational group for men in the present series. The finding that men currently living in a county? different from that of their birth were slightlyou taller than those still living in the same county: may be interpreted as being due to factors associa- $\vec{N}$ ted with their education and occupation. The observed variation in height by region of current? residence and region of birth conforms with obser $\vec{z}$ vations on Norwegian conscripts over the lasto several decades (Udjus, 1964). Differences in height by type of community were small when region waso controlled for. The persistence of these regionaf differences in the face of a strong general tree towards taller heights for successive cohorts may. indicate that they are mainly due to genetic differences. A case in point is the low heights in the nothernmost region, Finnmark, where the popula tion is characterized by its Lapp element.

Because of the secular increase in stature for $r_{2}^{\circ}$ successive cohorts, a weight gain with age among individuals is masked in comparisons between age 3 groups in cross-sectional data. Even differencesbetween age groups in weight for given height, or weight adjusted for height, in a simple index are not pure reflections of weight gain with increasing age,, since secular changes in bulk enter the picture. Due to the substantial differences in height between the two sexes, as well as to obvious sex-differences ing body build, the bulk values of the two sexes shoulde not be compared directly. Since women generallyo are less muscular and have less robust skeletons? than men, and as a result of their greater subcut-o aneous fat, the relative contribution of fatness to the value of the bulk index must, in general, bess greater in women. Since fat is the most labile bodyn tissue, and the bulk index may be assumed to be an more sensitive indicator of fatness in women than in men, one would expect differences and changes in relative adiposity to have greater effect on the bulk index in women than in men. Conversely when the pattern of variation in bulk seen in females is evidenced also by males, but to a smaller degree 
one may assume that differences in fatness, albeit possibly greater in females than in males, are the main source of this variation in both sexes.

Some features of the bulk index that were more pronounced in women than in men were:

(a) values differ by age group;

(b) values higher in ever married than in persons who had never married;

(c) variation by region of residence;

(d) variation by type of municipality of current residence, which was more pronounced than the variation by region;

(e) values higher in past smokers and in persons who had never smoked cigarettes than in current cigarette smokers;

(f) values higher in persons who stated that they took no physical exercise.

With age there is a relative increase in bulk in women compared to men and, particularly in women, in the ever married compared to those who remained single. That the last finding is caused by, rather than is a cause of, the married state is suggested by the fact that no such difference can be observed for the youngest age groups studied. Other observations of mine show bulk in married women to be positively associated with the number of pregnancies.

The finding that the bulk index varied more according to characteristics of current place, such as population density, rather than to its geographical location, is of interest in the light of the mortality statistics of Norway (Norway's Official Statistics, 1960, 1965). Total mortality in males is highest in towns and other densely populated municipalities and, in general, shows only minor regional variation within the various groups of municipalities. However, while mortality in females shows only a negligible association with population density, the negative association between bulk and the population density of the community was more evident in females than in males.

In keeping with these and other listed findings, indicating a greater propensity for weight changes in adult females compared to adult males, is the observation that only females demonstrated a stronger association of bulk with urbanization of current place than with urbanization of birthplace. The higher bulk values in persons born in rural areas, irrespective of urbanization of current place, are in accordance with data on Norwegian soldiers (Udjus, 1964). Differences in bulk due to dimensions of body build other than adiposity are probably more likely to be revealed in classifications reflecting experience in youth and young adulthood than in classifications more closely associated with recent experiences.

The confounding of muscularity and adiposity in the bulk index should be kept in mind when interpreting variation or lack of it between occupational groups. Contrary to the findings for height, the occupational variation in bulk did not reveal any consistent association with social class. In this respect the present series seems to conform with observations on Norwegian conscripts (Udjus, 1964) and with the results obtained in a study of Scotsmen by Clements and Pickett (1954), who found no significant variation in weight between social classes after adjustment for height and age.

The broad grouping of occupations in Table VII hides more striking differences between occupations. The higher weights for height among ships' officers than among non-officers found by Natvig and Vellar (1965) were also observed in the present series. In neither series did the non-officers differ conspicuously from men ashore in weight for height or in bulk. Differences in physical activity seem a likely explanation of the weight differences between the two groups, which in these respects are analogous to the groups of London bus drivers and conductors (Heady, Morris, Kagan, and Raffle, 1961; Oliver, 1967).

\section{SUMmary}

Patterns in variation in height, weight, and weight adjusted for height in the adult Norwegian population are reported. The data are derived from postal questionnaires completed by 19,000 respondents in a probability sample of the general population.

The relationship between weight and height, by sex and age, was investigated. Differences between age groups in weight for given height were greater in females than in males. For most comparisons the bulk index (weight)/(height) ${ }^{2}$, was used as a simple measure of weight adjusted for height. It is shown that, within age groups in both sexes, this index was more nearly uncorrelated with height than was the index (weight)/(height).

While height showed greater variation with region of residence than with density of population and the prevailing occupational pattern of current place, the opposite was true for the bulk index. Joint classifications according to the characteristics of birthplace and current place were employed to study associations with the two.

Men in professional and business occupations were taller than manual workers. Variation in the bulk index by occupational group did not reveal any consistent association with social class. The bulk index was higher in women who had married than in women who remained single, and in both sexes 
it was negatively associated with physical exercise and cigarette smoking.

The rationale for using the bulk index as an indicator of relative adiposity, and the reasons for its greater variation, in regard to a number of characteristics, in women than in men, are discussed.

This study was supported by U.S. Public Health Service contract No. PH 43-64-499.

\section{REFERENCES}

BAKLUND, C. J. (1962). Supplerende meddelelser om målinger og veiinger av skolebarn i Oslo gjennom 40 år. Skolehygiejnisk tidsskrift, 50, 69.

BenN, R. T. (1971). Some mathematical properties of weight-for-height indices used as measures of adiposity. Brit. J. prev. soc. Med., 25, 42.

Billewicz, W. Z., Kemsley, W. F. F., and Thomson, A. M. (1962). Indices of adiposity. Brit. J. prev. soc. Med., 16, 183.

Bøe, J., Humerfelt, S., and Wedervang, F. (1957). The blood pressure in a population. Blood pressure readings and height and weight determinations in the adult population of the city of Bergen. Acta med. scand., Suppl. 321.

Clements, E. M. B., and Pickett, K. G. (1954). Bodyweight of men related to stature, age, and social status. Weight of Scotsmen measured in 1941. Brit. J. prev. soc. Med., 8, 99.

Damon, A. (1965). Notes on anthropometric technique: III. Adult weight gain, accuracy of stated weight, and their implications for constitutional anthropology. Amer. J. phys. Anthrop., 23, 306.

EdWARDS, K. D. G., and WhYTe, H. M. (1962). The simple measurement of obesity. Clin. Sci., 22, 347.

Evans, J. G., and Prior, I. A. M. (1969). Indices of obesity derived from height and weight in two Polynesian populations. Brit. J. prev. soc. Med., 23, 56.

FloREY, C. D. DU V. (1970). The use and interpretation of ponderal index and other weight-height ratios in epidemiological studies. J. chron. Dis., 23, 93.

Heady, J. A., Morris, J. N., Kagan, A., and Raffle, P. A. B. (1961). Coronary heart disease in London busmen: A progress report with particular reference to physique. Brit. J. prev. soc. Med., 15, 143.

KHosla, T., and Lowe, C. R. (1967). Indices of obesity derived from body weight and height. Brit. J. prev. soc. Med., 21, 122.
Lindberg, W., NATVig, H., Rygh, Aa., and Svendsen, K. (1956). Høyde- og vektundersøkelser hos voksne menn og kvinner. T. norske L ageforen., 76, 361.

NatviG, H., and Vellar, O. D. (1965). Hoyde- og $\vec{F}$ Vektundersøkelser av Norske Sjømenn og Menn $i$ Land. Forskningsres. fra Landsforen. f. Kosth, og Helse. Melding 8, pp. 1-24, Oslo.

NoRWAY's OfFICIAL Statistics Series XII (1960). Medical Statistical Report 1957, p. 64. Central Bureau ${ }_{\odot}$ of Statistics of Norway, Oslo. - (1965). Health Statistics 1963, p. 46. \% Central Bureau of Statistics of Norway, Oslo. (1964). Population Census 1963, Vol. III, p. 280. Central Bureau of Statistics of Norway, Oslo. $\vec{\omega}$ Oliver, R. M. (1967). Physique and serum lipids of

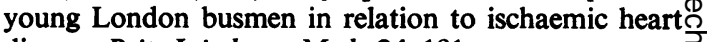
disease. Brit. J. industr. Med., 24, 181.

Pearl, R. B., LeVine, D. B., and Gerson, E. J. (1966). N Studies of disease among migrants and native popula- tions in Great Britain, Norway, and the United States $\overrightarrow{0}$ II. Conduct of field work in the United States. Nat. $\circ$ Cancer Inst. Monogr., 19, 301.

REID, D. D. (1966). Studies of disease among migrants $\vec{z}$ and native populations in Great Britain, Norway ando the United States. I. Background and design. Nat. Cancer Inst. Monogr., 19, 287.

-, Cornfield, J., Markush, R. E., Seigel, D., ठ্ Pedersen, E., and Haenszel, W. (1966). Studies $\mathrm{gf}_{-}^{-}$ disease among migrants and native populations $\mathrm{gn}$ Great Britain, Norway, and the United States. II I.-Prevalence of cardiorespiratory symptoms amougo migrants and native-born in the United States. Nat. Cancer Inst. Monogr., 19, 321.

RUFFer, W. A. (1970). Two simple indexes for identifyingo obesity compared. J. Amer. diet. Ass., 57, 326.

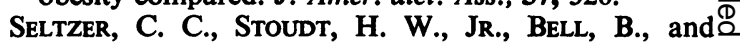
MAYER, J. (1970). Reliability of relative body weight $\vec{\overrightarrow{ }}$ as a criterion of obesity. Amer. J. Epidem., 92, 339.

Stoudt, H. W., Damon, A., McFarland, R., andROBERTS, J. (1965). Weight, Height, and Selected Body Dimensions of Adults. United States, 1960-1962. Pub. No. 1000-Series 11-No. 8. Public Health Service. U.S. Government Printing Office, Washington, D.C.

UDJus, L. G. (1964). Anthropometrical Changes in Norwegian Men in the Twentieth Century. Universitetsforlaget, Oslo.

WHYTE, H. M. (1965). Behind the adipose curtain. Studies in Australia and New Guinea relating too obesity and coronary heart disease. Amer. J. Cardiol., 15, 66. 